\title{
Development of Learning Management with the Application to Encourage Active Learning in Community: A Case Study of NTKB Application, Thailand
}

\author{
Khwanying Sriprasertpap and Suraches Meerith
}

\begin{abstract}
In the $21^{\text {st }}$ century, technology is important for learning and it needs to be cultivated for the young generation. Presently, the use of technology becomes a tool for learning without the limit of time, place, and content. In order to enhance the technology using skill for learning, therefore, the innovation development project has been organized. The purpose of this project was to develop the learning management with the application to encourage active learning in the community: a case study of NTKB Application, at the Botanical Garden in the Plant Genetic Conservation Project, initiated by Her Royal Highness Princess Maha Chakri Sirindhorn. The research project used the development methodology. Statistics for data analysis included percentage, mean, standard deviation and content analysis. The results found that Phase I Learning-Based in Local Community with Application Learning Model consisted of 7 key elements: 1) Analysis of Learner and Context 2) Pedagogies Design 3) Participant 4) Create Tools 5) Engagement and Evaluation 6) Merging Technology, and 7) Teaching and Learning with Technology. Phase II application usability was beneficial at a good level. The NTKB Application was beneficial for self-directed learners in local community and designing of application model to apply with other content, using APP-CEMT Model, AR technology application. In conclusion, it could transfer knowledge to learners and support their learning skills.
\end{abstract}

Index Terms-Active learning, local community, learning with application, learning management.

\section{INTRODUCTION}

In education 4.0, it is the age of connectivity learning, integrated learning in multi-content of other academics, and experienced learning from interest and capacity. The objective is the learner will change their behavior. The educational management must satisfy the learner and challenge them to create the learning process they want. When the learners engage with others in the learning process which is called active learning, it enhances the study result and increases the skill in using technology. They can search knowledge by themselves, from every type of learning media through knowledge application, analysis, synthesis, assessment, and creation.

In Thailand, education is considered a fundamental factor of human resources development and a mechanism for

Manuscript received January 3, 2020; revised February 22, 2020.

Khwanying Sriprasertpap is with the Department of Educational Technology, Srinakharinwirot University, Thailand (e-mail: khwanying@g.swu.ac.th).

Suraches Merith is with Bodhivijjakaya College, Srinakharinwirot University, Bangkok, Thailand (e-mail: suraches@g.swu.ac.th). developing the Thai economy and society. Education in Thailand has a long history reflecting the evolution of teaching and learning in the country and has gone through several major reforms for greater access to the education of people living in Thailand. [1] The Ministry of Education, therefore, has proposal for the implementation of education reform comprising the following important issues to be to reform 6 undertaken: 1) education and learning, 2) administrative structures and educational management, 3) teacher and educational personnel, 4) opportunities in education and educational quality, 5) workforce production and development to enhance the country's competitiveness, and 6) information and communication technologies for education. [2] In especially, reform information and communication technology for education which aims at improving ICT infrastructure for teaching and learning, developing databases and knowledge management, and etc. Therefore, technology and new media was to interesting to use for education and learning. In addition, the Thai government has policy to promote the use for new media to develop knowledge and skills of student in school and university.

Srinakharinwirot University is one of the leading research and learning organizations on a basis of virtue and education oriented to international innovation and creativity. There were mission to generate personnel development with quality and virtue for society through the learning process and a learning society and to create quality, beneficial and sustainable research and innovation for national and international society [3]. Srinakharinwirot University was to crate student to educator on process instructional design to blend between arts and science for pedagogies in teaching and learning in every faculty. In presently, the policies to support use active leaning and educational technology for lecturer. Center for Educational Media and Technology has the mission that is required to creatively produce and provide the media service to support learning with quality modern technology.[4] Academic Services and Training, therefore, has the concept of providing creative learning with innovation by developing the application for herbology learning (NTKB) at Plant Genetic Conservation Project under the Royal Initiation of Her Royal Highness Princess Maha Chakri Sirindhorn (RSPG), Ban Khlong Sai, Nong Takien Bon Sub District, Sa Kaeo Province, which deprives of the learning process that supports the learners to participate in the process until the comprehension. In consequence, the active learning management project with NTKB Application has been organized. The development of 
NTKB application is a collaboration between Center for Educational Media and Technology of Srinakharinwirot University and Nong Takien Bon Local Administration in Wattana Nakorn District, Sa Kaeo Province, which the operation is based on the research and to build the knowledge with the community for sustainable learning. Nong Takien Bon Local Administration is the informants of herbal contents to Center for Educational Media and Technology for creating the learning application and managing PR to invite the educational institutes in the sub-district to participate in the training of active learning management with NTKB application. This project was to create innovation in education and to develop knowledge for teaching to active learning in university and integrate academic with practice in local community between university and community needs.

\section{PRoblem AND OBJeCtive}

Regarding the literature review of learning by technology, it was found that the use of technology is able to increase the learning efficiency and the use of application is a new hot-trended technology used as a tool for many learning developments, especially knowledge and skills. Nonetheless, the study found that there is none of researching works developing the contents about plants and herbs or medical qualifications for those who are interested to learn and none of measurement and evaluation in affective domain; in other words, the awareness of environmental conservation. However, learning management process with application remains in the classroom without the learning integration in the community area. Furthermore, this process lacks the study of mutual demands and participatory media development from every sector including the community, the schools, the teachers, and the stakeholders. Therefore, the operation of this project aimed at developing the learning management with application to encourage active learning in the community and studying the result from using the learning management with application to encourage active learning in the community as creating the academic knowledge for usage. The aim of this research will be problem solving in learning with integrate technology to bring local knowledge to classroom in schools, students and teachers to practice to use technology application for leaning and use knowledge from application contents to diffusion with friends in schools.

\section{MethodOLOGY}

The methodology contains researching and development approaches, collecting qualitative and quantitative data. The research was divided into 2 durations as follows: Phase I Study and development of learning pattern with the application by visiting the site and dealing with community leader, local wisdoms, and teaches for 7 persons, as a mean to survey the spatial data for designing and developing the pattern, learning activities, and application development. The data from the interview would be analyzed its content, concluded, and applied to develop the application and learning activities.
Phase II Study the experiment of the learning by application by recruiting the participants from local administration and 23 network schools from Nong Takien Bon Sub-district School in Sa Kaeo Province. The sample group included 85 students, 20 teachers and officers, a total amount of 105 persons. They are divided into 8 groups, which each group contains a group leader and a facilitator and 10-11 students. The tools for data collection are evaluation of satisfaction by the project participants, content analysis, statistical analyses including percentage, mean, and standard deviation.

\section{RESULT}

\section{A. APP-CEMT Model}

The development of learning management with the application to encourage active learning in the community with the designing of learning to encourage active learning in the community and integration with the teaching in the school's system, as the design and the development operated by the author, the operation is the collaboration with local administration of Ban Khlong Sai in Sa Kaeo. The author focused on the community participation and knowledge transfer to personnel, teachers, and students in the community, using the community knowledge as the base, at Plant Genetic Conservation Project, Ban Khlong Sai, $\mathrm{Sa} \mathrm{Kaeo,} \mathrm{as} \mathrm{the} \mathrm{experimental} \mathrm{site} \mathrm{for} \mathrm{data} \mathrm{collection} \mathrm{in}$ accordance with System Development Life Cycle: SDLC [5]. The result of the development of learning management with the application is SWU CEMT having 7 components as follows: (Fig. 1).

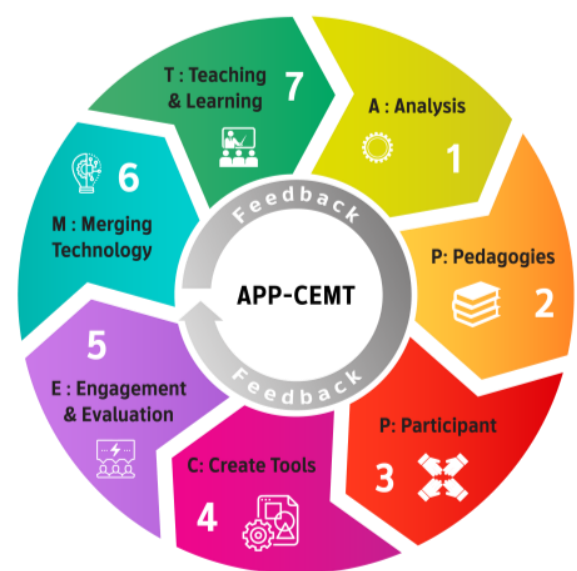

Fig. 1. APP-CEMT model.

1) A: Analysis Learner and Context is the first component which must analyze 2 parts which are the analysis of target group to examine their interest, their demands, or basic knowledge level, skills such as, portable computer skill, application skill. In terms of physical environmental and social contexts that facilitate the learning include supporting unit, budget, studying site, and participation of community schools and related units, it could be controllable and uncontrollable. The analyses consisted of necessity, condition, problems, and demands of the target group and related persons which would be concluded as fundamental data in developing 
the application in conformity with the target group and the learning management process.

2) P: Pedagogies Design After the analysis of target group and related contexts, it is required to design the pattern of learning management or instruction in order to transfer the knowledge and the use of the application, the design of curriculum and training or learning activities in combination with the use of application to encourage active learning so that the target group will operate and perform the reaction while the leader or the teacher is the facilitator. In this study, the project operator designed the learning as the activity base to study nature with a sheet and QR code to learn in a group, 10 members each and 1 leader each.

3) P: Participant The development of learning pattern and application in every step is a participatory process in which everyone can demonstrate ideas and practice, for instance, in the analysis to study the data from community leader, teacher, and local wisdoms, the interview asked problems, demands, and knowledge in the community that need to be transferred to the youth. Therefore, it concluded that the contents relating to herbs in the community's forest and the use of herbs as medicines and treatment for the development of the application. The original NTKB application contains 20 types of plants.

4) C: Create Tools After receiving the content to add in the application, the design and the creation of learning tools included NTKB application for Android System and IOS system, learning activities, and training courses for personnel and teachers in the community who want to use the application.

5) E: Engagement and Evaluation For the participation from every sector, to make participation in every related sector in order to apply the learning management for related persons recognizing its importance and the benefits of utilization in the community, in the school, and regular days. Due to the cooperation between home, school, community, and every sector, it reflects through the evaluation and opinions as the developers must have an opened heart to listen and apply the data to develop the most appropriate pattern for the real usage and the quality improvement which matches the demands of the target group and the participants who are group leaders and users. The evaluation of the official and unofficial interview, focus group, and the conclusion were utilized.

6) M: Merging Technology is the combination of current and appropriate technology towards learning in the learning process. For example, the development of NTKB Application is the combination of Augmented Reality technology with QR Code for data accessing and data representation in the form of description. In regards to the study, the result shows that this study focuses on participants learning the real plants in the community's forest; therefore, the use of voice-over only will let the users listen to the information and observe the trees through the group activity at the same time. And because of the far distance area, the internet signal is weak, the developer installed Offline function on the application so without the internet, the user is able to use the learning application.

7) $\mathrm{T}$ : Teaching and Learning with Technology, The final component if the transfer process through learning and practicing. This study arranged a training course for community leaders, personnel, and teachers who attended the project. The operator prepared sample media and materials for applying in the school and transfer the knowledge to other teachers or other interesting persons. According to the development of learning management with the application to encourage active learning in the community with the designing of learning to encourage active learning in the community: a case study of NTKB Application is the innovation development for learning by integrating application technology with learning management development for encouragement of the learning in a community, or the APP -CEMT Model, for later academic use and practice.

All of processes use feedback for approve and develop tasks in each components, it will be to quality in process, output and outcome. App-CEMT Model was design and develops from work process and local base in community and used for learning in informal and formal. In the future, we will to develop App-CEMT Model to integrate in University.

\section{B. NTKB Application}

NTKB Application is an application for learning by using the concept of participatory development between community, school, and educational institutes to support the use of technology in active learning management. The offline function is available. The characteristics of this application are to give information about plants in the Plant Genetic Conservation Project as the user accesses the data through $\mathrm{QR}$ and the application will give the botanic information of the plants through voiceover. The user will observe the plants and listen to the botanic qualification and information which could be applied in daily life. The developed NTKB Application supports the two operating systems which are Android and iOS. The instruction has 3 steps as follows:

1) Download NTKB Application

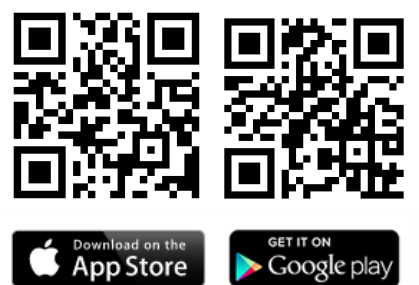

Fig. 2. Download and open the NTKB application.

2) Scan $Q R$ code of each plant with NTKB Application

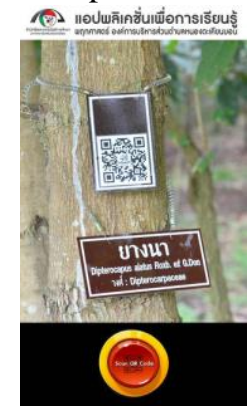

Fig. 3. The sample display QR code contents. 
3) Listen to the voiceover through NTKB Application

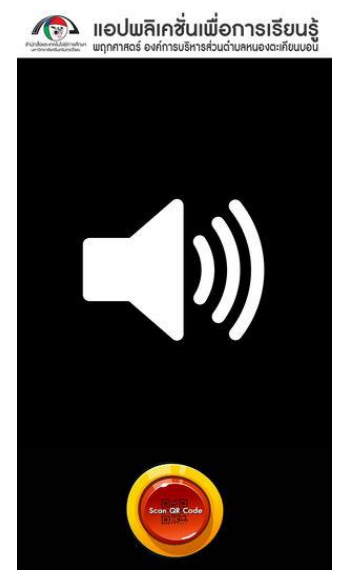

Fig. 4. The sample display voiceover through NTKB application.

\section{Usability}

Regarding the use of APP -CEMT to collect data from the target group with the satisfaction evaluation towards the use of NTKB application, the result is as seen in Tables I-II.

TABLE I: MEAN AND SATISFACTION LEVEL TOWARDS THE USE OF NTKB APPLiCATION By Teacher AND Personnel ( $N=20$ Persons)

\begin{tabular}{|l|c|c|}
\hline \multicolumn{1}{|c|}{ Question } & Mean & $\begin{array}{c}\text { Satisfaction } \\
\text { Level }\end{array}$ \\
\hline 1. The use of the application & $\mathbf{4 . 2 7}$ & Good \\
\hline 1.1 Appropriate content presentation & 3.83 & Good \\
\hline 1.2 Quality of Sound & 4.00 & Good \\
\hline $\begin{array}{l}1.3 \text { The data of plants in the application is } \\
\text { sufficient for the usage. }\end{array}$ & 4.33 & Good \\
\hline 1.4 Easy and convenient & 4.50 & Good \\
\hline 1.5 Sufficient function for the usage & 4.67 & Very Good \\
\hline 2. Utilization & $\mathbf{4 . 2 5}$ & Good \\
\hline $\begin{array}{l}\text { 2.1 The application benefits learning } \\
\text { management. }\end{array}$ & 4.00 & Good \\
\hline $\begin{array}{l}\text { 2.2 You can apply the concept of the } \\
\text { activity organization to learning } \\
\text { management. }\end{array}$ & 4.17 & Good \\
\hline $\begin{array}{l}\text { 2.3 You can use the application for the } \\
\text { integration of learning management in } \\
\text { other academics. }\end{array}$ & 4.33 & Good \\
\hline $\begin{array}{l}\text { 2.4 You intend to use the application of } \\
\text { self-learning management. }\end{array}$ & 4.50 & Good \\
\hline
\end{tabular}

TABLE II: MEAN AND SATISFACTION LEVEL TOWARDS THE USE OF NTKB APPLiCATION By STUDENT ( $N=85$ PeRsONS)

\begin{tabular}{|l|c|c|}
\hline \multicolumn{1}{|c|}{ Question } & Mean & $\begin{array}{c}\text { Satisfaction } \\
\text { Level }\end{array}$ \\
\hline 1 The use of the application & 4.40 & Good \\
\hline $\begin{array}{l}\text { 1.1The data of plants in the application is } \\
\text { sufficient for the usage. }\end{array}$ & 4.30 & Good \\
\hline 1.2 Student learns from the application. & 4.52 & Very Good \\
\hline 1.3 Sufficient function for self-learning & 4.21 & Good \\
\hline 1.4 Easy and convenient & 4.57 & Very Good \\
\hline 2 Utilization & 4.35 & Good \\
\hline $\begin{array}{l}\text { 2.1 Student can apply knowledge in daily } \\
\text { life. }\end{array}$ & 4.40 & Good \\
\hline $\begin{array}{l}2.2 \text { Student intends to transfer the } \\
\text { knowledge to accustomed people later. }\end{array}$ & 4.22 & Good \\
\hline 2.3 Student loves threes more. & 4.26 & Good \\
\hline $\begin{array}{l}\text { 2.4 Student intends to guard and conserve } \\
\text { forest more. }\end{array}$ & 4.56 & Very Good \\
\hline 2.5 Students will further knowledge of & 4.43 & Good \\
\hline
\end{tabular}

\begin{tabular}{|l|c|c|}
\hline \multicolumn{1}{|c|}{ Question } & Mean & $\begin{array}{c}\text { Satisfaction } \\
\text { Level }\end{array}$ \\
\hline their learning. & & \\
\hline $\begin{array}{l}\text { 2.6 Student is interested in creating their } \\
\text { own application. }\end{array}$ & 4.26 & Good \\
\hline 3 Learning Activity & 4.37 & Good \\
\hline $\begin{array}{l}\text { 3.1 Student feels fun with the learning } \\
\text { activity. }\end{array}$ & 4.55 & Very Good \\
\hline $\begin{array}{l}\text { 3.2 Student participates in the learning } \\
\text { activity. }\end{array}$ & 4.56 & Very Good \\
\hline $\begin{array}{l}\text { 3.3 Student feels fun with the use of this } \\
\text { application to search for the answer. }\end{array}$ & 4.45 & Good \\
\hline $\begin{array}{l}\text { 3.4 Student exchanges opinions with } \\
\text { friends. }\end{array}$ & 4.16 & Good \\
\hline $\begin{array}{l}\text { 3.5 Student practices their leadership and } \\
\text { followership through the activity. }\end{array}$ & 4.22 & Good \\
\hline $\begin{array}{l}\text { 3.6 Student practices how to present and } \\
\text { use technology. }\end{array}$ & 4.27 & Good \\
\hline
\end{tabular}

\section{DISCUSSION AND CONCLUSION}

In the development of the learning management with the application to encourage active learning in the community: a case study of NTKB Thailand Application, the conclusion comes from the academic sector and the operational sector in the collaboration of designing and developing the academic knowledge until creating APP CEMT Model before testing in the real target area. It could be applied in the classroom and daily life because the data in the application are the empirical data provided by local wisdoms and community leaders who want everyone is capable of learning and understanding plants and herbs, which will induce the awareness of the community's forest conservation in accordance with to King Rama 9 "Education, as key to human resource development, is a major focus of the King's Philosophy. Access to education is cited as a vehicle towards economic and political stability, reduction of inequalities and a better quality of life. Moreover, attention is given particularly to education for the underprivileged, rural and remote border areas, as well as hill tribes. In addition to schools, vocational skills development is supported by various sectors, including royal initiatives. Fostering ethics and morals, especially amongst the youth, is also regarded as an important element in the King's Philosophy". [6]

According to the use of NTKB Application, it was found that teachers and personnel rate the usage, regarding each aspect as follows: the application usage is at a good level with the mean at 4.27 but the sufficient function is at a very good level with mean at 4.67. it is probably because, in the design and the development of NTKB Application, the development selected participatory process with every sector including the community leaders, local wisdoms, and local teachers, resulting in the consistency of the application's functions and the demand. [7], [8]

For the lowest satisfaction which needs to be improved, the appropriate content representation has the mean at 3.83, which is probably because the content in the application is in a few numbers or just 20 topics. Due to the limit of learning in the real place and from the far distance where the internet signal is weak, the operating team, therefore, designed and developed the offline function to assist the distance learning. For this suggestion, the operating team shall be applied later for the application's performance improvement. 
In regards to the result among learners, it was evident that the highest means include the use of the application which has the mean at 4.40 or at a good level. To be specific, the students are attentive to guard and conserve forests more and they participated in learning activities which the mean is at 4.56 or at a good level. It is probably because the content and the activities they have learned are participatory active learning as they could take action in the real place and the content could be adapted in daily life, such as the medical qualifications of plants. The result of the innovation development is to share the knowledge of the community's forest for local people and people in Thailand by determining to apply the knowledge. It is expected that it will affect the awareness of forest conservation. If everyone sees the value of forest resources, humans and forests will sustainably live together and it will affect the good environment in the community and the country. This conforms to the goals in sustainable development of United Nation, Goal 15: the utilization of land ecological system that focuses on the environmental dimension and the world society. [9]-[11]

The suggestions for further researches are the application tool should be improved to be the web application for generally interested people, the design and the creation of the application for self-learning with more various patterns, for instance, adding images and sounds, sound only, 3D images, virtual images and augmented Reality. Moreover, the pattern, learning management with application, should be researched more. Regarding the suggestions for the implementation, the academic researching result could be the guidelines for the development of learning management or digital competence with technology and if there is the development of original application model with the private sector, [12] it might be evolved and registered for commercial use. The new ideas for develop content to VDO based online learning to solving lack of content from local knowledge to classrooms and publish content between teachers and communities, to professional learning community big data for online learning module. After that, you can to develop local curriculum in schools.

Future work extent form this paper, you can develop and change this platform to web application platform for everyone can connect content and can be integrate game simulation to create student's thinking, and use web application to connect content from other area to big data learning AR web application learning game and maybe extent research to online learning or ecotourism fieldtrip.

\section{CONFLICT OF INTEREST}

The authors declare no conflict of interest.

\section{AUTHOR CONTRIBUTIONS}

Assistant Professor Dr. Khwanying Sriprasertpap design methodology, conducted and wrote the case study, she also did data corrected and analysis with the team; Ajan Suraches Merith design and develop application. He corrected data in local areas with team. Both authors had approved the final version.

\section{ACKNOWLEDGEMENT}

This project was supported by Center for Educational Media and Technology, Srinakharinwirot University and Nong Takien Bon Sub District Administration Organization, Sa Kaeo Province, Thailand.

\section{REFERENCES}

[1] Office of the Education Council Ministry of Education, Education in Thailand, OBEC, Sukhothai Road, Bangkok, Thailand, 2017, pp. 12-14.

[2] Office of the Education Council Ministry of Education, Current Efforts and Way forward Education in Thailand, OBEC, Sukhothai Road, Bangkok, Thailand, p. 195, 2017.

[3] Srinakharinwirot University, Srinakharinwirot University Annual Report 2018, Thailand, pp. 14-17.

[4] Center for Educational Media and Technology, Center for Educational Media and Technology Annual report 2017, Srinakharinwirot University, Thailand, pp. 5-6, 2018.

[5] Suchai Thanawasatien and Other, Software Project Development. Sum Systems, Bangkok. Thailand, p. 32, 1999.

[6] Ministry of Foreign Affairs, "The king's philosophy," Towards Policy and Action in 2017, Bangkok. Thailand, pp. 161-164, 2017.

[7] M. Salam et al., "Technology integration in service-learning pedagogy: A holistic framework," Telematics and Informatics, vol. 38, 2019, pp. 257-273, 2019.

[8] S. Ivanna and K. Atik, "Pervasive learning and technology usage for creativity development in education," International Journal of Emerging Technologies in Learning(iJET), vol. 14, no. 1, 2019, pp. 95-109.

[9] United Nations Office for Outer Space Affairs, Sustainable Development Space4SDGs, Vienna International Centre, Austria, pp. 32-36, 2015

[10] N. F. Hassan et al., "Student understanding through the application of technology enabled active learning in practical training." Procedia Social and Behavioral Sciences, pp. 318-325, vol. 204, 2015.

[11] K. C. Stephen et al., "Interactivity, active collaborative learning, and learning performance: The moderating role of perceived fun by using personal response systems," The International Journal of Management Education, vol. 17, 2019, pp. 94-10.

[12] A. Sanglub, P. Nilsook, and P. Wannapiroon, "Imagineering on augment reality and digital twin for digital competence," International Journal of Information and Education Technology, vol. 9, no. 3, pp. 213-217, March 2019.

Copyright (C) 2020 by the authors. This is an open access article distributed under the Creative Commons Attribution License which permits unrestricted use, distribution, and reproduction in any medium, provided the original work is properly cited (CC BY 4.0).

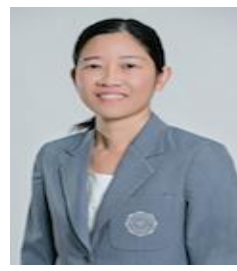

Khwanying Sriprasertpap is an assistant professor in the Department of Educational Technology, Srinakharinwirot University, Bangkok, Thailand. Presents she works in the field of ICT in education. She is director of Center for Educational Media and Technology (CEMT) since 2017.

Her research topics and interests include instructional design, behavioral science, e-training, database development, ICT management, active learning and application for learning and management.

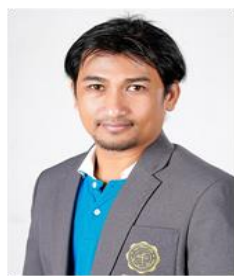

Suraches Merith is a lecture in Bodhivijjakaya College, Srinakharinwirot University, Bangkok, Thailand.

His research topics and interests include instructional design, application development and product design. 